\section{Wind of change at WMO}

\section{by John Gribbin}

THE World Meteorological Organisation (WMO) has acted promptly on the statement made by Dr Henry Kissinger to the sixth special session of the United Nations General Assembly calling attention to the possible implications of climatic change for global food and population policies. It has been decided to establish a "Panel of Experts on Climatic Change" with the terms of reference:

- To review present WMO activities relating to climatic change and to make recommendations on any additional steps which may be necessary to integrate these activities into a coherent programme.

- To act as the focal point for WMO activities on climatic changes, trends and fluctuations, and their implications on the natural environment of mankind and on world food production.

- To advise on any necessary measures for the coordination of these activities. - To advise on the policy implications for WMO of decisions of other international organisations relating to the impact of climatic changes.

Members of the panel have not yet been appointed, with the exception of the chairman Dr E. Süssenberger, who is a member of the Executive Committee of WMO and head of the German meteorological service.

The panel will meet as soon as possible and is requested to prepare a report in time for consideration at the Seventh Congress of WMO, next year.

At present, the WMO is active in several areas of climatic research, although these are not coordinated. Perhaps best known is the work on the physical basis of climate and climate modelling, which is being carried out jointly with the International Council of Scientific Unions (ICSU) within the framework of the Global Atmospheric Research Programme (GARP). There are several international conferences in the pipeline including one on "LongTerm Climatic Fluctuations" to be held at the University of East Anglia next August; a spokesman for the Climatic Research Unit there said last week that many participants have already accepted invitations to attend.

Other aspects of climatic research are at present being studied under the aegis of WMO by their Commission for Atmospheric Sciences (CAS), and there is also a Commission for Special Applications of Meteorology and Climatology (CoSAMC) working group looking into problems of "Climatic Fluctuation and Man". It is perhaps hardly surprising that the president of the Commission for Agricultural
Meteorology (CAgM) is about to appoint a Rapporteur on climatic fluctuations and food production, or that the WMO is preparing papers relating to climatic fluctuations for presentation at the World Food Conference in Rome in November 1974. But clearly the time is certainly ripe for one panel to coordinate all these activities, and also to relate observations by the World Weather Watch (WWW) to the WMO studies. The new panel will include experts nominated by CAS, CoSAMC, CAgM, and the Joint Organising Committee of GARP.

Among the possibilities considered by the WMO Executive Committee were to designate either the CAS Working Group on the Physics of Climatic Fluctuations or the CoSAMC Working Group on Climatic Fluctuations and Man as a panel of the Executive Committee overseeing the WMO's climatic work. But the committee decided "in view of the desirability of formulating proposals ... for consideration at the Seventh Congress, and bearing in mind the number of constituent bodies involved . . . to establish a [new] panel of experts" with the terms of reference as outlined above.

This panel will also be responsible for ensuring that WMO initiatives in this area are related to studies and work by other international bodies such as

\section{UK reactor choice}

by Eleanor Lawrence

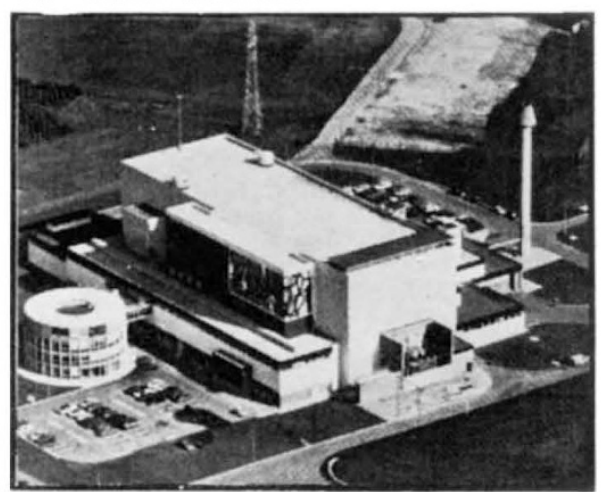

Winfrith SGHWR

Ar last the steam generating heavy water reactor (SGHWR) has been officially passed as the reactor choice for the next phase in the British nuclear power programme.

Announcing his decision in Parliament last week, Mr Eric Varley, Secretary of State for Energy, stressed five grounds on which he favoured the SGHWR.

- It will provide power reliably

- It can be ordered quickly

- The Nuclear Installations Inspec-
UNESCO, the Food and Agricultural Organisation (FAO), the United Nations Environmental Programme (UNEP) and ICSU. A UNEP representative at the recent WMO Committee meeting confirmed the desire of UNEP to be associated with WMO in further studies of climatic change, and mentioned particularly the possibility of accelerating "those aspects of the WMO programme which would be of value for planning food production, especially in the developing regions". He suggested that statements of the statistical probabilities of successive years of unfavourable weather conditions would be particularly useful.

A spokesman for the British Meteorological Office welcomed this development, and said that the Met. Office accepts the WMO view that the future of our climate is an important topic for study. He pointed out that although climatic change has been receiving more attention lately, this has included publicity for some "shakily based views" ranging from claims that a new ice age is just around the corner to fears that the Earth is heading for a global desert situation. So it is certainly, in the view of the Met. Office, a good thing for an authoritative study of this kind to be carried out, and to put the various claims made about climatic change into perspective.

torate will give it safety clearance quickly

- It offers scope for British technology which should be exploited - A $100-\mathrm{MW}$ prototype at Winfrith has been operating successfully for six years and is designed to produce the operating conditions of a commercial unit.

$\mathrm{Mr}$ Varley plans to start with modest reactor units of around 600 MW and an initial ordering programme of not more than $4,000 \mathrm{MW}$ over the next four years.

The government's decision runs counter to the strongly expressed wishes of the Central Electricity Generating Board (CEGB) in several respects. It wanted a large programme of a total of $36,000 \mathrm{MW}$ using the American pressurised water reactors (PWRs).

Doubts on the safety of the PWR have been expressed both in the United States and in Britain, notably by Sir Alan Cottrell, former Chief Scientific Adviser to the Government. The Select Committee on Science and Technology was also opposed to the PWR. One of the main attractions of the SGHWR is undoubtedly its safety. Unlike the PWR there is no large pressure vessel, but a system of small-diameter pres- 